\title{
Examining Trends of Indian Imports during the Period of 2002-2012
}

\author{
Payal K. Shah and Sannidhi R. Vyas
}

\begin{abstract}
Any country whether, rich or poor, small or big, cannot be completely self-sufficient. Irrespective of its position on the ladder of power, every nation needs either raw material or finished goods in order to meet internal demands. On the other hand, the less developed nations benefit due to their costeffectiveness, making trade a win-win for both. In short, every country is involved in import-export transactions. International trade has evolved over the years, while becoming more sophisticated, convenient and relatively safer. Risks have minimized due to a better legal structure pertaining to international trade which aims at protecting, both importers and exporters. Regulating and governing bodies such as the World Trade Organization (WTO) have streamlined the export-import system. Trade agreements like the North American Free Trade Agreement (NAFTA) have promoted growth of the foreign trade in various countries. Now it is relatively easier for smaller countries to go beyond borders and compete in the global market. This paper attempts to explore the behavior of Indian imports of chief commodities during the period 2002-2012 while ascertaining its buying patterns within this period. The paper also looks at the corresponding trends of Balance of Payments in order to get a clearer picture of the international trade scenario. The demand for more imported products is growing exponentially and businesses are taking these import-export opportunities seriously. However, the import demand is studied, keeping in mind the current situation of India as it gives a better idea about the factors affecting the same. Hence, the paper also looks at determining the factors affecting import demand by examining the current Indian economic situation.
\end{abstract}

Index Terms-Imports, international trade, demand factors, exports.

\section{INTRODUCTION}

Since the inception of planning, the external sector of the Indian economy has undergone significant transformation. The share of foreign trade in the country's GNP has been rising over the years. During the planning era, an expansion or rising trend of India's foreign trade is visible. Hence, this paper looks at the trends of major commodities imported in India during the period 2002-2003 to 2011-2012, trends in Balance of Payment during the same time frame and hence concluding with the major factors impacting Indian Imports. The sections of this paper include the major commodities imported, trends of total imported goods, Balance of Payment trends and the factors affecting total imports.

Manuscript received December 15, 2013; revised February 18, 2014

The authors are with the Pandit Deendayal Petroleum University, Gandhinagar, Gujarat, India 382007 (e-mail: payalshah2892@gmail.com, sannidhivyas@gmail.com).

\section{MAJOR INDIAN COMMODITIES IMPORTED}

The major commodities imported in India basically include bulk imports and non-bulk imports. Within bulk imports, there are petroleum and crude products, bulk consumption goods and other bulk items. Within bulk consumption goods there are cereals and cereal preparations, edible oils, pulses and sugar. Under other bulk items, there are fertilizers, crude, sulphur and unroasted Iron pyrites, manufactured goods, non-ferrous metals, paper, paperboards, manufactures including news prints, crude rubber including synthetic and reclaimed, pulp and waste paper, metalliferrous ores, metal scrap etc and Iron and steel. Non bulk imports basically include capital goods, mainly export related items and other goods. Capital goods include manufactures of metals, machine tools, machinery except electrical and electronic, electric machinery except electronic, electronic goods, computer goods, transport equipment and project goods. Mainly export related items include pearls, precious and semiprecious stones, organic and inorganic chemicals, textile yarn, fabrics, made-ups etc, cashew nuts. Others include Gold and Silver, artificial resins and plastic materials, professional and scientific controlling instruments, photographic optical goods, coal, coke and briquettes, medicinal and pharmaceutical products, chemical materials and products and non metallic mineral manufactures [1].

III. TREND OF TOTAL IMPORTS IN INDIA DURING 2002-2012

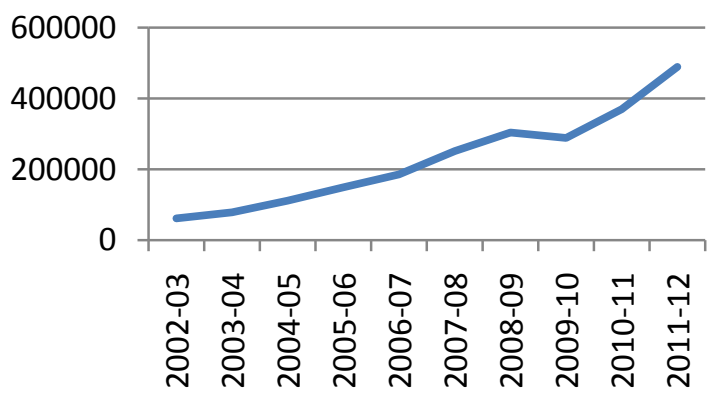

Fig. 1. Total imports (in US \$ million).

As shown in the Fig. 1, in the year 2002-2003, the total imports were US \$ 61412.1 million. The chief imports were done in the categories : a)Petroleum, Crude and Products, b)Pearls, precious and semi precious stones, c)Electronic Goods, d)Gold \& Silver,)Machinery (except electrical and electronic) [2].

Petroleum, Crude and Products imports amounted to US \$ 17639.5 million which was about $28.72 \%$ of the total 
imports. These were followed by the import of Pearls, precious and semi precious stones which amounted to US \$ 6062.8 million $(9.87 \%)$, import of electronic goods which amounted to US \$ 5599.4 million $(9.12 \%)$, import of Gold which amounted to US \$ 3844.9 million (6.26\%), and import of machinery excluding electrical and electronic which amounted to US \$ 3565.6 million (5.81\%) [2].

In the year 2003-2004, the total imports were US $\$ 78149.1$ million. The chief imports were done in the same categories as the previous year. Petroleum, Crude and Products imports amounted to US \$20,569.47 million which was about $26.32 \%$ of the total imports. These were followed by the import of Electronic goods which amounted to US \$ 7506.13 million (9.60\%), import of Pearls, precious and semi precious stones which amounted to US \$ 7128.66 million $(9.12 \%)$, import of Gold which amounted to US \$ 6516.89 million $(8.34 \%)$, and import of machinery excluding electrical and electronic which amounted to US \$ 3565.6 million (6.07\%). It is noteworthy that there was a sharp rise in gold imports $(69.49 \%)$. There was a substantial increase in import of electronic goods $(34.05 \%)$ as well as machinery $(33.04 \%)$. Therefore, while the amount of imports increased for Petroleum, Crude and Products, its share in the overall imports had decreased [2].

In the year 2004-2005, the total imports were US $\$ 111,517.43$ million. The chief imports were done in the same categories as the previous year. However, gold which already had an increasing demand during the previous year saw higher imports and had the second highest share in total imports following Petroleum, Crude and Products. Petroleum, Crude and Products imports amounted to US \$ 29844.10 million which was about $26.76 \%$ of the total imports. These were followed by the import of Gold which amounted to US \$ 10537.73 million $(9.45 \%)$, import of electronic goods which amounted to US \$ 9993.16 million $(8.96 \%)$, import of Pearls, precious and semi precious stones which amounted to US \$ 9422.71 million (8.45\%), and import of machinery excluding electrical and electronic which amounted to US \$ 6817.79 million $(6.11 \%)$. During this year, imports of Petroleum and crude products had a higher growth rate of $45.09 \%$. However, gold continued to see the highest growth rate in terms of imports which was $61.70 \%$. There was a substantial increase in import of the other three categories as well: electronic goods (33.13\%), machinery $(43.73 \%)$ and Pearls, precious and semi precious stones $(32.18 \%)$. Therefore, this year saw an overall increase in imports [2].

In the year 2005-2006, the total imports were US \$ $149,165.73$ million. The chief imports were done in the same categories as the previous year. Petroleum, Crude and Products imports amounted to US \$ 43,963.09 million which was about $29.47 \%$ of the total imports. These were followed by the import of Electronic goods which amounted to US $\$ 13,241.75$ million (8.88\%), import of Gold which amounted to US $\$ 10,830.52$ million (7.26\%), import of machinery excluding electrical and electronic which amounted to US \$ 10,009.81 million (6.71\%), and import of Pearls, precious and semi precious stones which amounted to US $\$ 9,134.42$ million $(6.12 \%)$. It is noteworthy that there was a sharp decrease in the growth rate of gold imports $(2.789 \%)$. The growth rate of imports of Pearls, precious and semi precious stones was negative with $-3.06 \%$. There was a substantial increase in import of Petroleum, Crude and Products $(47.31 \%)$ as well as machinery $(46.82 \%)$ [2].

The year 2006-2007 saw a change in the categories of chief imports. Pearls, precious and semi precious stones had been replaced by Transport equipments. The total imports were US \$ 185,735.24 million. Petroleum, Crude and Products imports amounted to US \$ 57,058.91million which was about $30.72 \%$ of the total imports. These were followed by the import of Electronic goods which amounted to US \$ $15,971.32$ million (8.60\%), import of Gold which amounted to US $\$ 14,474.10$ million $(7.79 \%)$, import of machinery excluding electrical and electronic which amounted to US $\$ 13,866.30$ million (7.47\%), and import of Transport equipments which amounted to US \$9,455.81 million $(5.09 \%)$. The growth rate of gold import increased to $33.64 \%$ from $2.789 \%$ in the previous year [2].

The year 2007-08 had total imports amounting to US \$ 251,654.00 million. Petroleum, Crude and Products imports amounted to US \$79,779.87million which was about $31.70 \%$ of the total imports. These were followed by the import of Electronic goods which amounted to US \$ 20,661.71 million (8.21\%). The import of transport equipments saw the highest growth rate which was about $113.30 \%$ and it amounted to US \$20,169.26 million $(8.01 \%)$. The growth rate of gold import decreased to $14.70 \%$. Import of Gold amounted to US \$16,601.30 million $(6.60 \%)$ and import of machinery excluding electrical and electronic which amounted to US \$ 19,901.62 million $(7.91 \%)$ [2].

The year 2008-09 saw the re-entry of Pearls, precious and semi precious stones which replaced Transport equipments to be a part of chief imports. At US $\$ 16,804.02$ million, Pearls, precious and semi precious stones saw a jump of $111.27 \%$ in growth rate. The Petroleum, Crude and Products imports amounted to US \$93667.19 million which was about $30.84 \%$ of the total imports. This category was the only one to have a substantial share in the total imports amounting to US \$303,696.31 million which was $30.84 \%$. The percentage share of rest of the commodities was between $5-7 \%$ [2].

The year 2009-2010 was the year where the total imports had dip to US \$288,372.88 million with a negative growth rate of $-5.05 \%$. This owed to the negative growth rate of imports in several product categories like Petroleum, Crude and Products $(-6.97 \%)$, electronic goods $(-10.72 \%)$, machinery excluding electrical and electronic $(-9.36 \%)$ and Pearls, precious and semi precious stones (-3.01\%). However, gold saw a very high growth rate of $41 \%$ as compared to the other categories. This could be attributed to the increased levels of disposable income, because in Indian economy, Gold is seen as an important part of savings [2].

Following the previous year where the imports recorded a low, the year 2010-2011 brought along with it positive growth rates in imports. The total imports were US $\$ 369,769.13$ million with a positive growth rate of $28.23 \%$. Petroleum, Crude and Products saw a rise of $21.61 \%$ in the growth rate. Gold continued at about the same growth rate as that of the previous year which was $41.09 \%$. Imports of Pearls, precious and semi precious stones showed a sharp rise in the growth rate which was $112.41 \%$ [2]. 
In the year 2011-2012, the total imports were US \$ 489,319.49 million. Petroleum, Crude and Products imports amounted to US \$154,967.55 million with a growth rate of $46.24 \%$. These were followed by the import of Gold which amounted to US \$56,501.71million with a growth rate of $38.97 \%$. The growth rate of import of Pearls, precious and semi precious stones which amounted to US $\$ 28,199.64$ million saw a sharp decrease at $-18.54 \%$ [2].

Hence, if we examine the chief commodities, it can be seen that imports in the category Petroleum, Crude and products have been steadily rising except for the year 20092010 where it saw negative growth rate in imports. The case is similar for Electronic good s and Machinery (excluding electrical and electronic), where the growth rate of imports saw a negative figure only in the year of 2009-2010 and were steadily increasing otherwise. On the other hand commodity categories like Gold and Pearls, precious and semi precious stones have shown different patterns. The growth rate of gold imports has been continuously rising since 2002. Whereas, the pattern of imports in the Pearls, precious and semi precious stones category is the most fluctuating one and hence, is the most unpredictable and unsteady category in the group of chief commodities imported throughout the decade.

\section{TRENDS OF THE INDIAN BALANCE OF PAYMENT DURING 2002-2012}

Balance of Payments (BoP), being a record of the monetary transactions over a period with the rest of the world, reflects all payments and liabilities to foreigners and all payments and obligations received from foreigners. In this sense, the balance of payments is one of the major indicators of a country's stand in international trade. BoP accounting serves to highlight a country's competitive strengths and weaknesses and helps in achieving balanced economic growth.

Reasons for the major change in trends during 2003-2004 (peak), 2005-2006 (trough), 2007-2008(peak) 2008-2009 (trough), 2009-2010 (peak) and 2010-2011 and 2011-2012 are as follows:

As shown in the Fig. 2, during the year 2003-2004, capital account surplus was almost double its previous year's level. While major components of loans (e.g. external assistance and commercial borrowings) recorded net outflows, foreign investment flows increased more than three-fold. Heavy portfolio inflows, comprising essentially FII investment, shored up total foreign investment and the overall capital account surplus. Banking capital inflows, particularly expatriate deposits, also contributed to the expanding surplus [3].

Fall in the balance of payment in the year 2005-2006 can be attributed to the rate of increase in imports more than that of increase in exports (along with the rise in oil prices). In India, a large proportion of the international oil price increase has traditionally been absorbed by the government (and shared with public sector oil producing and retailing companies) [6]. This led to trade deficit and hence affecting the current account balance. In the capital account balance the main difference arises in the other flows (delayed exports receipts and errors and omissions) as compared to the previous year where there is a difference of US \$ 9501 million [4].

During the year 2007-2008, as seen in the Fig. 2, BoP reaches the highest peak. As compared with the previous year's data, even though the rise in imports is more than that of exports i.e. trade balance is more negative as compared with previous year's data but the high net invisibles (transactions related to international trade in services, income associated with non residential assets and liabilities, labor and property, and cross border transfers, mainly workers' remittances) is high that offsets the result of high trade deficit. However the current account deficit is high compared with the previous year.

But looking at the components of capital account, it can be observed that there is rise in external assistance (net), commercial borrowing (net), high foreign investments including the Foreign direct investments, foreign portfolio investments and other flows such that there is a rise of US\$ 63,027 million as compared with the previous year.

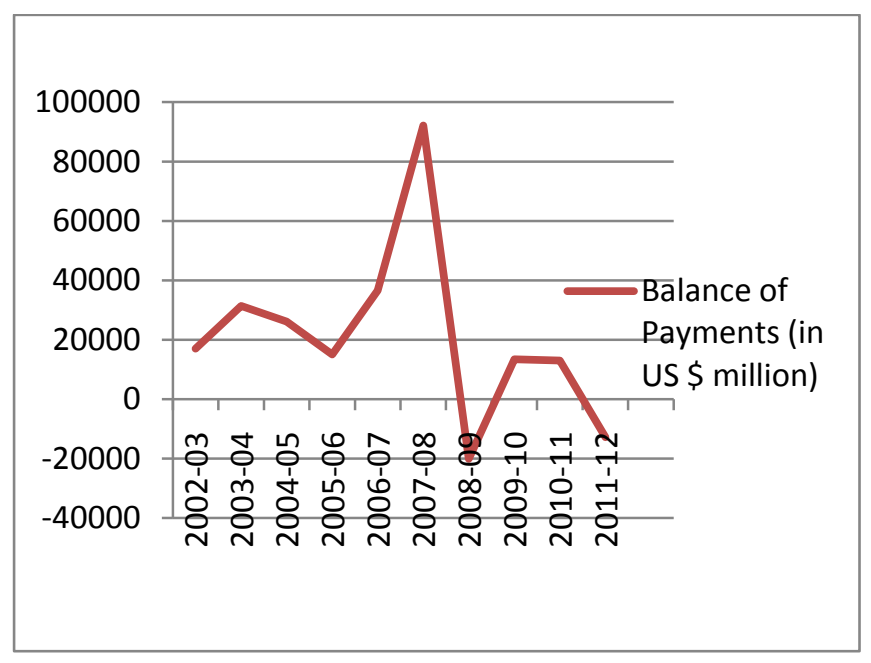

Fig. 2. Balance of the payment dyring the period of 2002-2012 (in US\$ million)

Hence, such a rise in capital account offsets the fall in current account and makes the BoP for the year 2007-2008 reach its highest peak in the timeframe observed [5].

The BoP reached its lowest point in the year 2008-2009. The main components of the current account that can be attributed to this fall are trade balance (fall in US $\$ 27,183$ million as compared with the previous year) and goods and services balance (difference between trade balance and non factor services, fall in US \$16,405 million as compared with the previous year).Now the components in the capital account like fall in net external commercial borrowing and heavy fall in net foreign investments (about US\$ 39,859 million i.e $91.99 \%$ fall in net foreign investments compared with the previous year that is enough to reduce the capital account to only US\$ 8648 million). The foreign exchange reserves fell by about US\$ 20080 million). The fall in foreign investments can be attributed to the global financial crisis in 2008 that badly impacted the major developing countries [5].

The BoP reached its second highest (peak) in the year 2009-2010. The exports and imports both fell during this period due to which the gap in trade deficit (trade imbalance) fell by US\$ 1316 million. However this fall in trade deficit 
does not impact much as there is fall in the invisibles and goods and services deficit also rises. In the capital account, there is a rise in net external assistance, short term-debt, banking capital and substantial rise in net foreign investments (net FDI and net portfolio foreign investments) from US\$ 8,342 million in 2008-09 to US\$50,362 in 20092010 that increases its overall balance ( BoP) to US\$13,441 million [5].

The next fall in BoP after the year 2008-2009 is 20112012. Both the exports and the imports rise during this period, but the increase in imports is much higher than the increase in exports. There was $20.93 \%$ increase in exports whereas the imports rose by $30.26 \%$ as compared with the previous year due to which there is a trade imbalance of US\$ $1,89,759$ million and the current account deficit becomes US\$ 78,155 million. The capital account during this time period does not influence the Balance of Payment as it actually rises a little as compared with the previous year. Hence main factor for the fall in overall balance and the foreign exchange reserves that falls to US\$12,831 million is the current account deficit (CAD) [5].

\section{MAJOR FACTORS AFFECTING INDIAN IMPORTS}

\section{A. Macroeconomic Conditions and Government Policies in the Importing Country}

Trade deficit as well as current account deficit when increases and have crossed the bearable limit, it influences the Indian imports as the government may impose heavy custom duty or import duty or can be in the form of quota, allowing only a fixed amount of commodities to be imported [7], [8]. However this may not be very effective as it may lead to smuggling of some goods like gold due to insufficient supply. With the clearance in certain imports duties, it leads to fresh import orders, like during September 2013; about $250 \mathrm{~kg}$ of gold was stuck at Mumbai Airport due to stricter government and the central bank's norms to limit the imports that were aggravating the current account deficit. It was only after certain new orders of the government that those stalled, amount of gold with the customs department got released [9].

Other Internal factors that may impact the imports can be the prices in domestic country. When the prices in the domestic country fall heavily due to higher global supplies at cheap prices or even more domestic supply, the government may intervene in terms of imposing import duty to control the prices of that commodity. The Government in July 2013, had increased the import duty on sugar from $10 \%$ to $15 \%$ in order to keep a check on prices [10].

Also, when the inflation in the importing country rises, may be due to excessive demand or incapability of the country to produce such that quantity supplied falls, the imports may rise. However, even with the increasing demand in the country importing goods, the imports can rise. In India it is said that the imports of electronic goods will outstrip the oil imports by 2020 to reach $\$ 400$ billion as the usage of PCs, tablets and smart phones is on the rise and also the government is trying to focus on products like smart phones, tablets, set top boxes, micro ATMs, smart cards, and smart energy meters that have maximum demand in the country [11].
In order to protect the domestic industry, country can impose an anti - dumping duty to discourage imports. For e.g. The Government of India imposed an anti dumping duty of $\$ 9 / \mathrm{kg}$ on import of European Union bulk drug Cefadroxil Monohydrate which is being used in pharmaceutical industry [12]. However, the lack of required attributes in the domestic goods ultimately derives the country to increasing imports. For example, the ash content in domestic coal can be as high as $40 \%$, compared with $10 \%$ in imported coal. The gross calorific value (GCV) of domestic coal is $3,000-3,500 \mathrm{Kcal} / \mathrm{kg}$ while that of imported coal is $5,000-7,000 \mathrm{Kcal} / \mathrm{kg}$.

Any new rule or policy may not have an immediate effect, it takes time to respond (lag effect). Liberalizing imports was a crucial element of the IMF- World Bank stabilization package for India. It was designed to enhance economic efficiency, accelerate growth, arrest inflationary pressures and benefit trade balance [13]. Yet, the effects of these policy changes did not come immediately. With the new $80 / 20$ trade tying rule by the Reserve bank of India, traders said that it took them 10 days to actually understand the complexity of such policies. It is only after the banks that are the major importing agencies for gold into India made those complexities clear the traders continued with their fresh orders of imports. Various new reforms of tying the imports with the exports leads to reduction in annual demand of gold (fell during June-July 2013 due to this reason). Even after certain import and custom duties by the government to make the imports costlier and hence to discourage them, the demand for the product imported may not fall even though imports may fall. Hence it all depends upon the elasticity of the country (depending upon the alternatives it has for the product being imported) and also elasticity of the ultimate buyers and the customers as they are the ones who drive the demand for these imports.

\section{B. International Issues}

The recent agreement one in which Iran signed a treaty with 6 powers that led to the lessening of the sanctions imposed on Iranian exports with the return of Iran controlling its nuclear program, may affect Indian oil imports from Iran as it can increase the oil imports from Iran (India is the second largest buyer of oil from Iran after China). Also the removal of European Union's sanctions on insurance opens the door for India as well as other oil importers like Japan, China and South Korea [14].

\section{Decisions by Exporting Country}

Any decision by an exporting country to rein its exports may affect Indian imports directly. Indonesia that restricted its coal exports to India may affect companies that are heavily dependent on Indonesia as 2/3 rd of Indian power plants run on coal unlike some of the private players like Adani power and Tata power as they import coal from other south east Asian countries also. Hence along with the exporting countries putting any restrictions, it is also number of suppliers that might influence Indian imports. Any sanctions imposed by the superpower on the country regarding its foreign trade may affect Indian imports. Adducing, During May 2013, US had imposed certain trade restrictions on Iran due to its expanding nuclear program which Iran had mentioned it being meant only for peaceful 
purpose. This sanctions imposed on Iran resulted in reduction in oil imports by India by almost a fifth since December 2012 [15].

\section{Currency Value}

Falling rupee makes the imports costlier due to which the imported commodity may lose sheen as the burden of increase in price falls on buyer only. India, the third largest producer of Apple is the highest Apple importer due to seasonality, geographical separation and limited infrastructure amid rising demand from an expanding middle class which recently lost shine because of falling rupee [16]. Due to recent fall in rupee value (rupee reached at a low of 68), government imposed an import duty on gold which increased from $6 \%$ to $8 \%$ to $10 \%$ that makes import of gold costly affecting imports and also according to the new rule, gold importers must export $20 \%$ of their imports by value addition (in the form of gems and jewellery), however if the global demand is weak which affects the exports for products like gems and jewellery, it automatically affects the import of the raw material i.e. gold. With the fall in rupee and rise in the price of commodity imported, imports are affected. For e.g. with the recent fall in Indian rupee coupled with rise in the price of natural gas the imports had to be reduced as even the subsidies had to be increased (with rise in price of natural gas). Volatility in rupee's value impacts the commodities imported. For e.g. During September 2013, when rupee had reached a low of about 68 as per dollar, imports of vegetable oil that comprises of edible and non edible oils had dipped by $15 \%$. Further, the changes in currency flexibility have not been preceded by announcements from RBI. Currency flexibility has risen and dropped without this information being transparently shared with economic agents. This information matters directly to economic agents with currency exposure, who need forecasts of currency volatility for making decisions on currency hedging [17].

\section{E. Impact of Rise in Price of Gold Imported}

Indian silver imports were on pace to hit a record high as the wedding and festival season drove up buying of the precious metal instead of the traditional gold, made scarcer and dearer by official measures aimed at cutting the trade gap and also the prices of silver metal is quite low. Gold is 60 times costlier if compared in dollar terms. However silver cannot be used as substitute of gold as gold has certain alternatives like best hedge against inflation, as gift as it is considered auspicious in religious ceremonies also and for marriages and festivals. Since Indian farmers who form up to about $60 \%$ of the people contributing to gold demand, the rise in their disposable income makes them demand more quantity of gold, hence overall demand for gold imports rises [18].

\section{F. Macroeconomic Factors in the Country Exporting Goods}

If there is inflation in other countries, government of those countries may opt for dumping duties making it unattractive for exporting countries as the cost rises. Also quota ban for restricting the goods exported may impact Indian imports.

\section{G. Geographical and Environmental Factors}

With the fall in supply or scarcity in the domestic geography, importing goods leads to rise in the commodities imported. For e.g. India's natural rubber imports more than tripled in September 2013 as tapping activity has been adversely affected by rains. So tyre makers had to ramp up imports to ease supplies. Presence of certain harmful chemicals if detected or observed may result in import ban of such commodities. For e.g. , India that had banned Chinese milk and dairy products like including chocolates and chocolate products and candies/confectionary/food preparations with milk or milk solids as an ingredient as it was feared that it contained melamine - a deadly chemical. Also, various priorities of the government like curbing air pollution and protecting struggling domestic miners affect import decisions [19].

\section{H. Others}

Even the non coverage of the insurance of the refineries can lead to reduction in imports. Adducing, In March 2008, India had to halt Iran oil imports due to the non coverage of the refineries importing oil without the insurance cover is accompanied with higher risks [20].

Hence, there is a wide range of factors that have been able to influence a country like India [21]-[23].

\section{ACKNOWLEDGMENT}

We extend our gratitude to the faculty members of the Economics Department, Pandit Deendayal Petroleum University, for their constant support and guidance.

\section{REFERENCES}

[1] Business Portal of India: Government of India, Indian Economy, Investment, Incentives, Trade, Infrastructure, Legal Aspects. (n.d.). Business Portal of India: Government of India, Indian Economy, Investment, Incentives, Trade, Infrastructure, Legal Aspects. [Online]. Available: http://www.business.gov.in

[2] Table 129: Exports of Principal Commodities - Us Dollar. [Online]. Available: http://rbidocs.rbi.org.in/rdocs/Publications

[3] Balance of Payments. [Online]. Available: http://indiabudget.nic.in/es2003-04/chapt2004/chap62.pdf

[4] Balance of Payments. [Online]. Available: http://indiabudget.nic.in/es2005-06/chapt2006/chap62.pdf

[5] Table 140: India's Overall Balance of Payments. [Online]. Available: (n.d.).http://rbidocs.rbi.org.in/rdocs/Publications

[6] N. R. Bhanumurthy, S. Bose, and S. Das. (2012). Oil price shock pass-through policy and its impact on India. NIPFP, 2012-2099. [Online]. Available: http://www.nipfp.org.in/media/medialibrary

[7] PTI, P. Chidambaram: Indian Economy Stressed, Hard Decisions Coming Soon, The Financial Express, September 7, 2013.

[8] Bureau, Gold, Silver Import Duty Raised to Rein in CAD, The Financial Express, August 14, 2013.

[9] Reuters, Indian Gold Buyers Rush to Order Now Import Rules are Clear, The Financial Express, September 4, 2013.

[10] Reuters, India Notifies Sugar Import Duty Hike to $15 \%$ from 10\%, The Financial Express, July 9, 2013.

[11] Bureau, Electronics Imports to Reach $\$ 400$ bn by 2020: IT Ministry, The Financial Express, February 15, 2013.

[12] PTI, India Slaps $\$ 9 / \mathrm{kg}$ Duty on Import of European Union Bulk Drug, The Financial Express, October 21, 2013.

[13] Reuters, India Considers More Iran Oil Imports, Readies Payments of 'Billions of Dollars', The Financial Express, November 26, 2013.

[14] Bureau, Indonesias Plan to Regulate Coal Exports Worries Indian Importers, The Financial Express, July 1, 2013.

[15] PTI, Falling Indian Rupee Takes Shine off India's Apple Imports: USDA, The Financial Express, August 25, 2013.

[16] Reuters, Starved of Gold, Indians May Import Record Volumes of Silver, The Financial Express, October 9, 2013. 
[17] B. Pattanayak, Natural Rubber Imports Triple in September, The Financial Express, Retrieved : November 1, 2013.

[18] P. Ryles, India to Halt Import of Iranian Oil, The Epochtimes. Retrieved: November 4, 2013.

[19] S. Mukerjee, "The impact of liberalizing imports-India, a case study," Journal of Developing Areas, vol. 28, no. 4, pp. 521-534, 1994.

[20] I. Patnaik, Indian Currency Regime and its Consequences, National Institute of Public Finance and Policy, 2007, vol. 49, pp. 11-12.

[21] V. N. Murti and V. K. Sastri, "Elasticities of Demand for Certain Indian Imports and Exports," Sankhya: The Indian Journal of Statistics (1933-1960), vol. 11, no. 3-4, pp. 309-336, 1951.

[22] M. Dutta, "Import Structure of India," The Review of Economics and Statistics, vol. 47, no. 3, pp. 295-300, 1965.

[23] E. Dayal, "Changing patterns of India's International Trade," Economic Geography, vol. 44, no. 3, pp. 240-269, 1968.

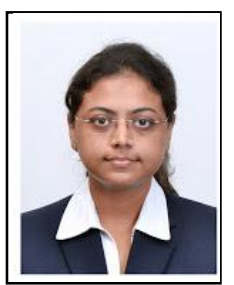

Payal K. Shah was born in Surat, Gujarat, India in the year 1992. She is currently a final year student pursuing a B.A. (Hons.) in economics from School of Liberal Studies, Pandit Deendayal Petroleum University, Gujarat, India with major subject as economics and minor subject as business administration.

She has wrote a paper titled 'Analyzing buying behavior of laptops for students' which was published as a part of conference proceeding organized by IIT Delhi, India. She has also presented a paper titled 'Changing trends of Iron Ore Exports during the period 2002-12' at RDA International Conference, Jaipur. She has been a committee member of the university's economics club. She has undergone internships at the District Municipal Corporation, the directorate of economics and statistics and at a consultancy service company as a live project trainee.



Sannidhi R. Vyas was born in Ahmedabad, Gujarat, India in the year 1993. She is currently a final year student pursuing a B.A. (Hons.) in economics from School of Liberal Studies, Pandit Deendayal Petroleum University, Gujarat, India with major subject as economics and minor subject as business administration.

She has presented a paper titled 'Taming the dragon: A mammoth task?' at the national conference held at Pandit Deendayal Petroleum University. She has also presented a paper titled 'Exploring trend of Indian Fiscal Deficit as compared to various macroeconomic variables' at RDA International conference, Jaipur. She has undergone internships at the District Municipal Corporation and in the field of journalism, social research and NGOs. She is a certified user of SPSS software. 